\title{
Article
}

\section{Sargassum Influx on the Mexican Coast: A Source for Synthesizing Silver Nanoparticles with Catalytic and Antibacterial Properties}

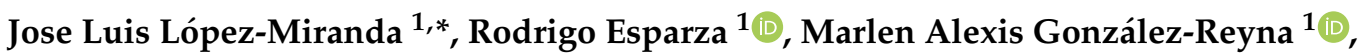 \\ Beatriz Liliana España-Sánchez ${ }^{2}{ }^{\mathbb{D}}$, Angel Ramon Hernandez-Martinez ${ }^{1} \mathbb{D}$, Rodolfo Silva ${ }^{3}(\mathbb{D}$ \\ and Miriam Estévez ${ }^{1, *}$ \\ 1 Centro de Física Aplicada y Tecnología Avanzada, Universidad Nacional Autónoma de México, \\ Boulevard Juriquilla 3001, Santiago de Querétaro 76230, Mexico; resparza@fata.unam.mx (R.E.); \\ marlengonzalez@fata.unam.mx (M.A.G.-R.); angel.ramon.hernandez@gmail.com (A.R.H.-M.) \\ 2 CONACYT_Centro de Investigación y Desarrollo Tecnológico en Electroquímica SC, Parque Tecnológico \\ Querétaro s/n Sanfandila, Pedro Escobedo, Qro. 76703, Mexico; lespana@cideteq.mx \\ 3 Instituto de Ingeniería, Universidad Nacional Autónoma de México, Coyoacán, Mexico City 04510, Mexico; \\ rsilvac@iingen.unam.mx \\ * Correspondence: lopezfim@gmail.com (J.L.L.-M.); miries@fata.unam.mx (M.E.)
}

check for

updates

Citation: López-Miranda, J.L.; Esparza, R.; González-Reyna, M.A.; España-Sánchez, B.L.; HernandezMartinez, A.R.; Silva, R.; Estévez, M. Sargassum Influx on the Mexican Coast: A Source for Synthesizing Silver Nanoparticles with Catalytic and Antibacterial Properties. Appl. Sci. 2021, 11, 4638. https://doi.org/ 10.3390/app11104638

Academic Editor: Elza Bontemp

Received: 17 April 2021

Accepted: 17 May 2021

Published: 19 May 2021

Publisher's Note: MDPI stays neutral with regard to jurisdictional claims in published maps and institutional affiliations.

Copyright: (c) 2021 by the authors. Licensee MDPI, Basel, Switzerland. This article is an open access article distributed under the terms and conditions of the Creative Commons Attribution (CC BY) license (https:// creativecommons.org/licenses/by/ $4.0 /)$
Abstract: This work reports, for the first time, the synthesis of silver nanoparticles using extracts of the species of Sargassum natans and Sargassum fluitans (AgNPs-S). Their antibacterial and catalytic properties are compared with silver nanoparticles obtained by chemical synthesis (AgNPs-C). The characterization of AgNPs-S and AgNPs-C was carried out using ultraviolet-visible spectroscopy (UV-Vis), dynamic light scattering (DLS), zeta potential, a scanning electron microscope (SEM), X-ray diffraction (XRD), Fourier transform infrared spectroscopy (FTIR), and thermogravimetric analysis. The synthesis of silver nanoparticles using Sargassum extract was optimized through varying experimental parameters, such as the type of solvent used to prepare the extract, the volume of the extract, and the $\mathrm{pH}$ of the system. The most efficient sample (AgNPs-S) was prepared with a water-ethanol-based extract, using a 3:1 volumetric ratio of extract: a precursor salt with the addition of $1 \mathrm{~mL}$ of $\mathrm{NaOH} \mathrm{pH}=14$. The AgNPs-C were spherical in shape, with an average particle size of $11.55 \mathrm{~nm}$, while the AgNPs-S were polyhedral shaped, with an average particle size of $26.39 \mathrm{~nm}$. The synthesized AgNPs-S were found to have significantly higher catalytic activity for the degradation of methylene blue and more effective antibacterial activity against Staphylococcus aureus and Pseudomonas aeruginosa than AgNPs-C.

Keywords: Sargassum extract; silver nanoparticles; catalytic activity; antibacterial activity

\section{Introduction}

For years, the surface waters of the Caribbean and western central Atlantic were considered oligotrophic, with low surface chlorophyll, and hence occasionally described as "ocean deserts" [1]. Nevertheless, in 2009 and 2010, massive phytoplankton blooms were recorded in the eastern Caribbean. Satellite information showed that such events had not occurred in the previous 30 years [2,3]. Even so, the following year, the same unusual case was seen, and since 2011, huge amounts of Sargassum have been reported intermittently in what was until then known as the Atlantic Sargassum belt [4,5]. The unusual is becoming the usual, as aggregations of Sargassum have washed up on the shores around the Caribbean, with a maximum of over 20 million metric tons in June 2018 [4,6]. Chavez et al. [7] reported for the Mexican Caribbean yearly averages of $3.2 \times 10^{3}$ and $1.7 \times 10^{3} \mathrm{~m}^{3} / \mathrm{km} / \mathrm{month}$ for 2018 and 2019 , respectively.

The enormous amount of Sargassum and its rotting on the waterfront is far from attractive to visitors, bringing about anxiety on the part of the travel industry [7]. In addition, 
negative environmental consequences on the coastline are a cause for concern [8-10]. The solution was seen to be the mechanical collection of Sargassum before its arrival on beaches and tourist destinations. However, this, too, produces problems [11-20]. The management and disposal of the collected Sargassum has, as yet, been little studied. Storing it or burying it seems unviable, due to the contamination produced; the problem has simply been moved inland.

On the other hand, in recent years, the synthesis of nanoparticles using molecules present in plants, fungi, bacteria, or algae has been hailed as an ecofriendly process, often labelled "green synthesis" or "biosynthesis". Thus, many studies have been undertaken on biosynthesized silver nanoparticles (AgNPs), thanks to their excellent natural physicochemical properties [21-26]. The biosynthesis of AgNPs using the biomolecules of Sargassum seems to offer a win-win solution, with unwanted Sargassum collected on the Mexican Caribbean being used for sustainable activity for the inhabitants of the region, and the actual collection of the Sargassum from the shore being given added value. This type of algae has a high bioactive compound content, which includes polysaccharides and terpenoids [27]. Its ability as a reducing agent is attributed to these types of phenolic compounds [28], while polysaccharides are involved in the stabilization of nanoparticles [27]. It has recently been reported [29] that Sargassum species arriving on the Caribbean coast have a high phenolic compound content, which can be used to reduce metal ions.

The objective of this research was, therefore, to explore the use of this collected Sargassum as a source of reducing agents and stabilizers for the green synthesis of metallic nanoparticles. As AgNPs have been extensively studied, they are the obvious first choice for green synthesis, since the range of reported data allows for a broad comparison with other sources of synthesis. The results of synthesizing AgNPs using Sargassum as a natural source for the green synthesis of AgNPs are presented, along with their catalytic activity by means of methylene blue degradation and antibacterial properties against Staphylococcus aureus and Pseudomonas aeruginosa.

\section{Materials and Methods}

\subsection{Materials}

The Sargassum used in this work was collected from the Mexican Caribbean coast. Previous studies indicate that the Sargassum arriving in this region is a mixture of two species: Sargassum natans and Sargassum fluitans [29,30]. Analytical-grade $\mathrm{AgNO}_{3}$ was used as the precursor salt for the synthesis of AgNPs. For the chemical synthesis of the nanoparticles, $\mathrm{NaBH}_{4}$ and polyvinylpyrrolidone (PVP) were used as reducer and stabilizer agents. Both reagents are of analytical grade. Reagent-grade $\mathrm{NaOH}$ was used to vary the $\mathrm{pH}$ of the green synthesis. Reagent-grade methylene blue was used to evaluate the catalytic properties of silver nanoparticles. All the reagents were purchased from SigmaAldrich. The aqueous solutions of chemical reagents and dilutions were prepared using distilled water.

\subsection{Preparation of Sargassum Extract}

Sargassum extract was obtained by the infusion method. The Sargassum was given several washes, using distilled water, to remove dirt and sand. Then, $1 \mathrm{~g}$ of Sargassum was weighed out and placed in a $100 \mathrm{~mL}$ beaker, and $50 \mathrm{~mL}$ of the solvent used was added to the beaker. In this study, three solvents were evaluated: water, ethanol, and a water-ethanol mixture (50\%). The mixture was subsequently stirred magnetically for $30 \mathrm{~min}$ at $60{ }^{\circ} \mathrm{C}$. The mixture was then filtered, using Whatman \# 41 filter paper, and the liquid extract was allowed to cool to room temperature, then refrigerated and stored at $4{ }^{\circ} \mathrm{C}$ for later use.

\subsection{Green Synthesis of AgNPs}

The synthesis of AgNPs using the Sargassum extract was carried out by mixing the $10 \mathrm{mM} \mathrm{AgNO}_{3}$ solution, prepared with distilled water, with the extract. The experimental was conducted at room temperature under resting conditions. First, the type of extract was 
evaluated using $2 \mathrm{~mL}$ of $\mathrm{AgNO}_{3}$ mixed with $1 \mathrm{~mL}$ of the extract obtained with a different solvent (water, ethanol, or 50\% water-ethanol). Subsequently, the volumetric ratio between the extract and the precursor salt was varied, in such a way that ratios 1:4, 1:3, 1:2, 1:1, 2:1, $3: 1$, and $4: 1$ were evaluated. Finally, the change in $\mathrm{pH}$ was evaluated, adding $1 \mathrm{~mL}$ of a $\mathrm{NaOH}$ solution of a different $\mathrm{pH}$ value $(8,10,12$, and 14$)$. The samples obtained were stored for later UV-vis characterization. Once the UV-vis characterization was carried out, the most efficient sample was selected according to the characteristics of the absorption peak. Only this sample was named AgNPs-S, and it was used to perform the characterization and to evaluate the catalytic and antibacterial properties.

\subsection{Chemical Synthesis of AgNPS}

The chemical synthesis of AgNPs was carried out based on the chemical reduction method previously reported in the literature [31,32]. Four $\mathrm{mL}$ of PVP, which acts as a stabilizing agent, were added to $4 \mathrm{~mL}$ of $10 \mathrm{mM} \mathrm{AgNO}_{3}$ in a $50 \mathrm{~mL}$ beaker. Subsequently, $10 \mathrm{mM} \mathrm{NaBH}_{4}$ was gradually added, at a rate of $100 \mu \mathrm{L}$ per minute, until $4 \mathrm{~mL}$ was added. The mixture was kept at room temperature under magnetic stirring for $3 \mathrm{~h}$. Finally, this sample, called AgNPs-C, was stored for later analysis and characterization.

\subsection{Characterization of AgNPs}

Silver nanoparticles, obtained by both green and chemical methods, were characterized using different techniques to determine their physical characteristics. UV-vis spectroscopy was performed using a METASH 5000M spectrophotometer. The spectra were recorded between 800 and $200 \mathrm{~nm}$, with a step of $1 \mathrm{~nm}$, using quartz cells. The nanoparticle samples were diluted with distilled water in a 1:10 ratio. X-ray diffraction was used to determine the crystalline nature and crystal size of the AgNPs-S and AgNPs-C, using a a Rigaku Ultima IV diffractometer. The radiation used was $\mathrm{Cu} K \alpha$ and the $2 \theta$ degree range was from 20 to $80^{\circ}$.

The morphology and particle size of the AgNPs-S and AgNPs-C were evaluated using a Hitachi SU8230 cold-field emission scanning electron microscope with a voltage of $1 \mathrm{kV}$. The particle size distributions were calculated by dynamic light scattering (DLS), using a Litesizer 500 from Anton Paar. The measurements were taken with a semiconductor laser diode $(\lambda=658 \mathrm{~nm})$ with a fixed side angle $\left(90^{\circ}\right)$ and a disposable cell in automatic mode, with the instrument optimizing the number of runs, the optical filter, and the focus position. The data were collected with a measurement duration of $10 \mathrm{~s}$ and the temperature of the sample at $25^{\circ} \mathrm{C}$. The colloidal stability was determined using zeta potential with the Litesizer 500 as an average of three measurements. For this analysis, the samples AgNPs-S and AgNPs-C were placed into an Anton Paar Univette reusable cuvette. The temperature was set at $25^{\circ} \mathrm{C}$ and the $\mathrm{pH}$ value of the dispersed silver nanoparticles was adjusted by adding aqueous $1 \mathrm{M} \mathrm{HNO}_{3}$ or $1 \mathrm{M} \mathrm{NH}_{3} \mathrm{OH}$. The amount of water, organic compounds, and, consequently, the silver concentration in the AgNPs-S and AgNPs-C samples were determined by thermogravimetric analysis (TGA), using a Mettler Toledo TGA/DSC 2+ thermal analyzer. The analysis was performed with a heating rate of $10{ }^{\circ} \mathrm{C} / \mathrm{min}$ between 30 and $700{ }^{\circ} \mathrm{C}$. Finally, Fourier transform infrared (FTIR) spectroscopy was used to determine the functional groups present in the organic compounds of the Sargassum extract. The compounds involved in the reduction and stabilization of the AgNPs were synthesized with the Sargassum extract, using a Perkin Elmer Spectrum Two FTIR spectrometer. On dried samples, the FTIR spectra were recorded using a wavelength from 400 to $4000 \mathrm{~cm}^{-1}$.

\subsection{Catalytic Properties of AgNPs}

Catalytic activity was evaluated through the degradation of methylene blue. The concentration of the dye was evaluated at 1,2,3,4, and $5 \mathrm{ppm}$. According to the TGA results, the concentration of the AgNPs-S and AgNPs-C samples was $2.23 \mathrm{mg} / \mathrm{mL}$ and $3.8 \mathrm{mg} / \mathrm{mL}$, respectively. Therefore, the AgNPs-C was diluted to obtain the same concentration, that is, $2.23 \mathrm{mg} / \mathrm{mL}$. The degradation reaction was carried out by adding $30 \mu \mathrm{L}$ of nanoparticles to 
$10 \mu \mathrm{L}$ of $20 \mathrm{mM} \mathrm{NaBH}_{4}$ and $1 \mathrm{~mL}$ of methylene blue in a quartz cell. The degradation of methylene blue was analyzed by UV-vis spectroscopy, monitoring the intensity of the dye absorption band, which appears at $664 \mathrm{~nm}$ in the ultraviolet-visible spectrum.

\subsection{Antibacterial Properties of AgNPs}

Gram-positive Staphylococcus aureus \#6538 and gram-negative Pseudomonas aeruginosa \#13338 were purchased from American Type Culture Collection (ATCC) and grown in Luria Bertani media (LB). The antibacterial activity (AA) of AgNPs-S and AgNPs-C was evaluated by the microdilution method. Different concentrations of AgNPs were used $(1000,500,250,125$, and $62.5 \mu \mathrm{g} / \mathrm{mL})$ suspended in a phosphate buffered saline (PBS) media at $1 \mathrm{wt} . \%$ as a dispersant agent. The PBS buffer $(200 \mathrm{~mL})$ was prepared with $159.24 \mathrm{mg}$ of $\mathrm{KH}_{2} \mathrm{PO}_{4}, 258.6 \mathrm{mg}$ of $\mathrm{K}_{2} \mathrm{HPO}_{4}$, and $1.753 \mathrm{~g}$ of $\mathrm{NaCl}$ dissolved in distilled water. The interaction of bacteria and AgNPs were evaluated after 1 and $24 \mathrm{~h}$ of contact, in three independent, duplicated experiments. First, inoculums of each microorganism were grown in LB media at $37^{\circ} \mathrm{C}$ for $16 \mathrm{~h}$ and adjusted by optical density to obtain a final concentration of $2 \times 10^{5} \mathrm{CFU} / \mathrm{mL}$. A 1:1 mix of bacteria and nanoparticles was performed at 1 and $24 \mathrm{~h}$ and incubated at $37^{\circ} \mathrm{C}$. An aliquot $(50 \mu \mathrm{L})$ of each sample was plated in LB dishes and incubated at $37^{\circ} \mathrm{C}$ for $16 \mathrm{~h}$. AA was calculated following the methodology of previous work [21]. Data were subjected to statistical analysis using one-way ANOVA with Minitab $19.2{ }^{\circledR}$, followed by Tukey's comparison test.

\section{Results and Discussion}

Some important parameters can be considered in the green synthesis process to obtain highly stable nanoparticles, such as the selection of the best plant and the optimization of the reaction conditions: for example, light, temperature, $\mathrm{pH}$, mixing speed, concentration, etc. The optimization of these crucial factors could affect the morphology and other properties of the nanoparticles [33,34]. Therefore, we first propose modifying the solvent used to make the extract, the salt concentration, and the $\mathrm{pH}$ in order to obtain a synthesis route that provides silver nanoparticles with a monodisperse size, with good catalytic and antibacterial properties.

Figure 1a shows the UV-vis analysis of the AgNPs samples synthesized with the three solvents at a 1:2 volumetric ratio of extract salt. When the ethanol Sargassum extract is employed, no absorption peak is observed, suggesting the nonpresence of AgNPs. On the other hand, when the extract obtained with water is used, an absorption peak appears at $441 \mathrm{~nm}$, which is a characteristic surface plasmon resonance (SPR) band for silver. However, this peak is very wide and has a very low intensity, indicating a low concentration of nanoparticles of a wide size range. Finally, the spectrum corresponding to the sample in which the water-ethanol Sargassum extract is used shows an absorption peak at $432 \mathrm{~nm}$. Furthermore, the absorption peak has a high absorbance, suggesting a high concentration of AgNPs. Figure $1 \mathrm{~b}$ shows the UV-vis spectra by varying the volumetric ratio of extract salt using the water-ethanol Sargassum extract. As seen, as the volume of extract increases, the AgNPs absorption peak increases in intensity, indicating an increase in the concentration of nanoparticles. Regarding the position of the AgNPs absorption peak, there is no significant variation. In all the spectra, this signal is between $422 \mathrm{~nm}$ and $430 \mathrm{~nm}$. 

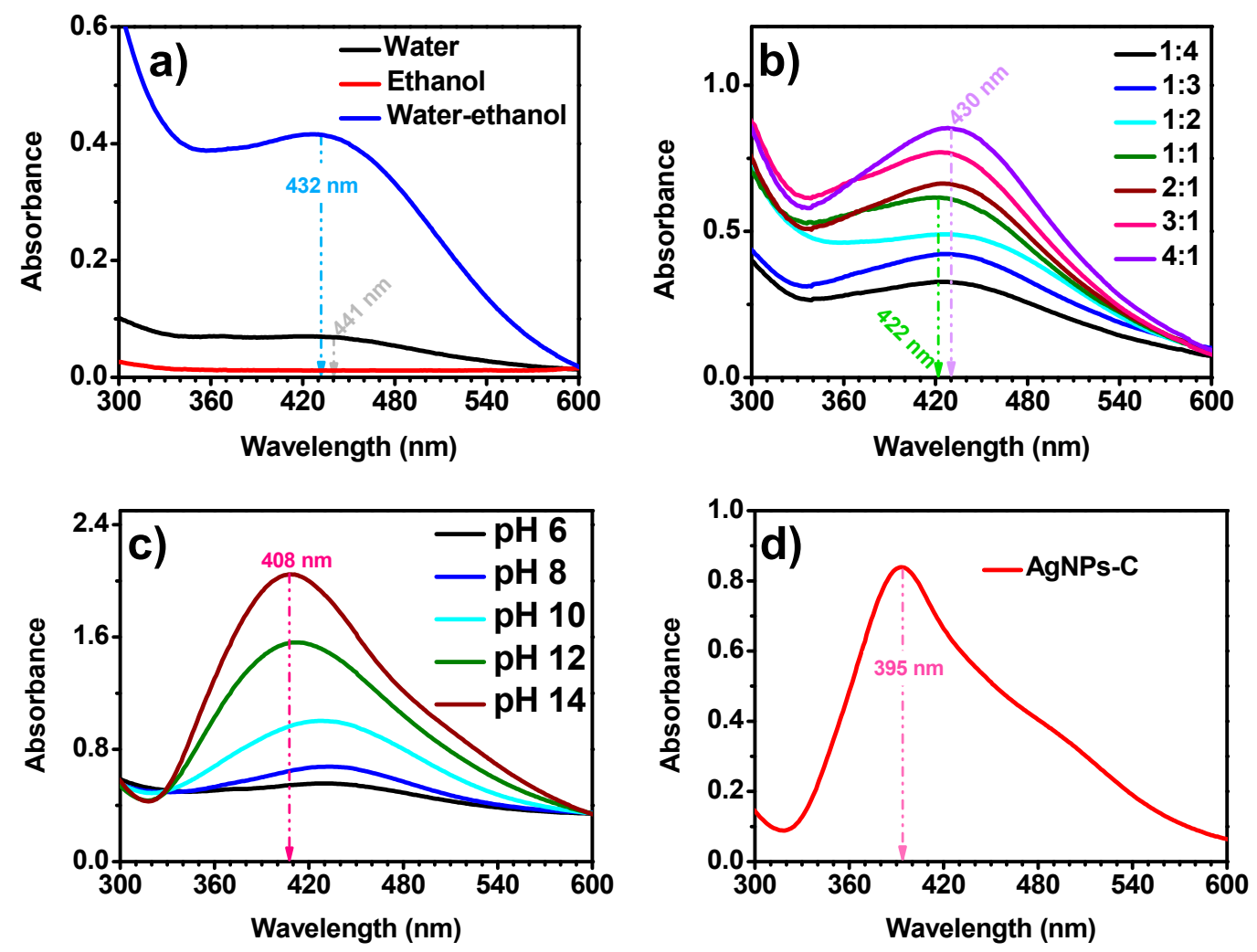

Figure 1. UV-vis analysis of the AgNPs synthesized with Sargassum extract, varying: (a) the extracting solvent (the volumetric ratio of extract:salt was 1:2), (b) the water-ethanol extract:precursor salt volumetric ratio, and (c) the $\mathrm{pH}$ of the $\mathrm{NaOH}$ solution added, using the water-ethanol extract with an extract:salt volumetric ratio of 3:1. (d) The UV-vis spectrum of AgNPs synthesized by the chemical method.

Although the spectrum corresponding to the 4:1 ratio shows a more intense absorption peak, its position $(430 \mathrm{~nm})$ and width suggest the presence of larger AgNPs, with a wide size dispersion. Thus, the spectrum with the absorption peak of greatest intensity, centered at the lowest wavelength $(422 \mathrm{~nm})$, is that of the 3:1 volumetric ratio. Therefore, this sample was selected for the subsequent analysis. According to various reports [35-37], the synthesis of uniform and monodisperse nanoparticles occurs most readily in alkaline conditions. Figure 1c shows the UV-vis spectra of the samples in which $1 \mathrm{~mL}$ of $\mathrm{NaOH}$ is added at different $\mathrm{pH}$ values. It can be seen that, as a $\mathrm{NaOH}$ solution of higher alkalinity is used, the absorption peak of the AgNPs increases significantly. Furthermore, as far as its position is concerned, the peak shifts towards shorter wavelengths. In this way, the sample with $\mathrm{NaOH}(\mathrm{pH}=14)$ shows the most intense absorption peak, centered at $408 \mathrm{~nm}$, indicating the presence of a high concentration of AgNPs of a small and uniform size. Therefore, the most efficient sample was selected to carry out the characterization and evaluation of the antibacterial and catalytic properties. This sample is named AgNPs-S from here on. The selection was carried out based on the comparison of all UV-vis spectra. As can be seen, AgNPs-S corresponds to the sample in which the water-ethanol-based extract was used with a volumetric extract:precursor salt ratio of 3:1 and a $\mathrm{pH}=14$ - that is, the sample corresponding to the dark red spectrum in Figure 1c. Finally, Figure 1d shows the UV-vis spectrum of AgNPs-C obtained by chemical synthesis, using $\mathrm{NaBH}_{4}$ and PVP as reducing and stabilizing agents, respectively. The spectrum shows a narrow peak, centered at $395 \mathrm{~nm}$, suggesting the presence of small nanoparticles with a narrow dispersion of size. This sample, named AgNPs-C, was used to compare the catalytic and antibacterial activities of the nanoparticles. 
Figure 2 shows the X-ray diffraction (XRD) patterns of the prepared AgNPs. Figure 2a shows the XRD pattern of the AgNPs-C obtained from the conventional chemical reduction method, where diffraction peaks at $2 \theta=38.20^{\circ}, 44.22^{\circ}, 64.55^{\circ}$, and $77.91^{\circ}$ were assigned to (111), (200), (220), and (311) planes, respectively, of the face-centered cubic (fcc) lattice of Ag (JCPDS No. 87-0597). The XRD pattern of the AgNPs-S (Figure 2b) shows similar diffraction peaks of $\mathrm{Ag}$ with a fcc lattice. However, other diffraction peaks were observed at $2 \theta=31.76^{\circ}$ and $45.50^{\circ}$, corresponding to the cubic phase of sodium chloride ( $\mathrm{NaCl}$, JCPDS No. 75-0306), and a further diffraction peak was observed at $2 \theta=34.80^{\circ}$, corresponding to the cubic phase of potassium chloride (KCl, JCPDS No. 75-1674). NaCl and $\mathrm{KCl}$ phases may be associated with seawater residues in the Sargassum, since it was only shade dried, hand crushed, and washed with deionized water. The crystallite size of the nanoparticles was calculated using the Debye-Scherrer equation [38], using the half width of the intense (111) reflection. The results were 10.12 and $23.85 \mathrm{~nm}$ for the AgNPs-C and AgNPs-S samples, respectively. The values of the crystallite sizes are close to those measured with STEM images, showing that the particles are single crystal.

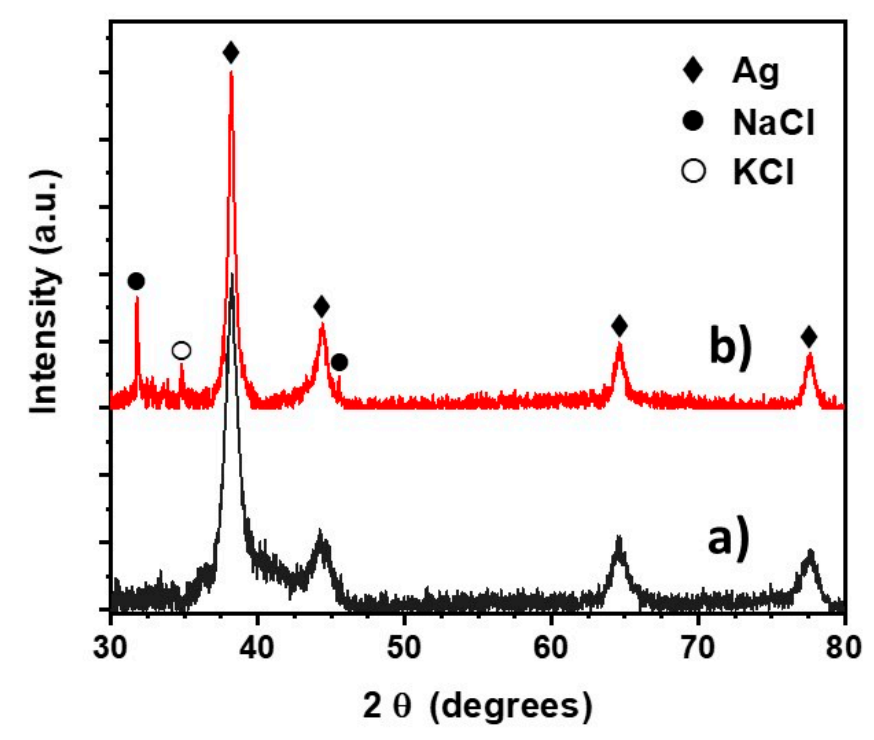

Figure 2. X-ray diffraction patterns of: (a) AgNPs-C and (b) AgNPs-S.

It is known that the antibacterial effect of AgNPs is closely related to their size and shape $[39,40]$. Therefore, an exhaustive characterization is recommended to understand the properties of the nanoparticles obtained. Figure 3 shows the bright field-scanning transmission electron microscopy (BF-STEM) images of the AgNPs obtained. Figure 3a shows the BF-STEM image of the AgNPs-C. As can be observed, the AgNPs-C have homogeneous particle sizes. Figure $3 \mathrm{~b}$ shows a BF-STEM image of higher magnification. It is clear from the image that there are no agglomerates in the sample and that the morphology of the nanoparticles is almost spherical. The average particle size seen in the BF-STEM images was $11.55 \mathrm{~nm}$ (Figure 3c). Figure 3d shows the AgNPs-S, which have different morphologies from the AgNPs-C. In this case, most of the nanoparticles are polyhedral in shape (Figure 3e). In the inset of Figure 3e, a color look-up table (LUT) image clearly illustrates that the nanoparticle (green) is coated by an organic compound (yellow) from the Sargassum extract. The average particle size of the STEM images, corresponding to AgNPs-S, was $26.39 \mathrm{~nm}$ (Figure 3f) greater than the AgNPs-C. It has been reported that polyhedral AgNPs (decahedral) have higher bactericidal activity than spherical AgNPs [41], as the (111) surface planes are more catalytic than the (100) surface planes; therefore, despite the size difference, we would expect AgNPs-S to have an enhanced antibacterial effect. 

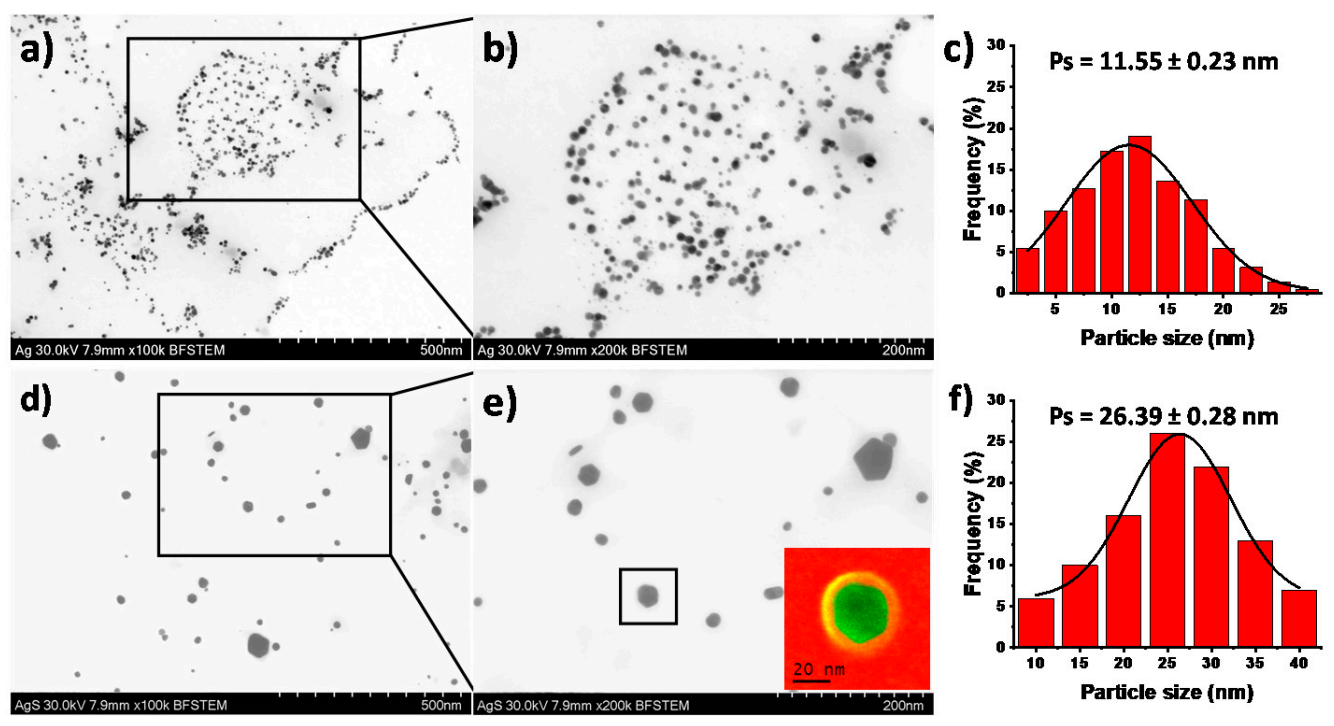

Figure 3. (a,b) BF-STEM images of the AgNPs-C, (c) corresponding plot of the particle size distribution; (d,e) BF-STEM images of the AgNPs-S, (f) corresponding plot of particle size distribution.

The DLS technique was also used to determine the particle size and size distribution profile of the AgNPs. To carry out this analysis, the AgNPs-S and AgNPs-C samples were diluted in order to set the concentration at $0.223 \mathrm{mg} / \mathrm{mL}$. Figure 4 shows that the average particle size of the AgNPs-C was $12.71 \mathrm{~nm}$, with a standard deviation of $0.739 \mathrm{~nm}$. For the AgNPs-S, the average particle size was $27.59 \mathrm{~nm}$ with a standard deviation of $3.38 \mathrm{~nm}$. As can be seen, the dispersion of the nanoparticle size corresponds to a single modal distribution for both samples; however, AgNPs-S shows a wide particle size distribution as observed by BF-STEM. The average particle size determined by DLS was slightly larger than that determined by BF-STEM. This is because the DLS technique measures the mean hydrodynamic diameter of the AgNPs coated by the organic layer, and this hydrodynamic diameter is affected mainly by the viscosity and concentration of the medium. On the other hand, BF-STEM only gives the diameter of the nanoparticles obtained from processed images with high contrast. It is clear from the BF-STEM images and DLS values that there were no aggregates. The almost complete nonaggregation of both samples and their good size homogeneity is an outstanding result because these characteristics are usually very difficult to achieve, in particular with green-synthesized nanoparticles.

The zeta potential is a key indicator of the stability of colloidal dispersions. This technique gives a measurement of the "effective" electric charge on the nanoparticle surface and quantifies the charge stability of the colloidal nanoparticles. Particles with a negative zeta potential will bind to positively charged surfaces, and vice versa. Hence, the zeta potential also suggests how the particle will interact with other nanoparticles. Therefore, this becomes an important parameter when designing a nanoparticle for a specific application. Figure 5 shows the results of the zeta potential analysis. Data collected from the silver nanoparticles show negative potentials, with values of less than $30 \mathrm{mV}$, which indicates good physical stability of both nanosuspensions and guarantees that the particles do not aggregate. The sign minus is mostly conferred by the radical groups, such as carboxylic and hydroxyl radicals, present at the surface of the nanoparticles. As can be seen, the zeta potential becomes more negative as the solution goes from acid to alkaline. At $\mathrm{pH} 3$ both types of nanoparticles exhibit almost the same zeta potential, but, as the $\mathrm{pH}$ is increases, the zeta potential of AgNPs-S falls lower than that of AgNPs-C. This suggests that in alkaline media, the AgNPs-S nanoparticles are more stable and explains why at $\mathrm{pH}$ 14 , the synthesis of uniform and monodisperse nanoparticles occurred. 


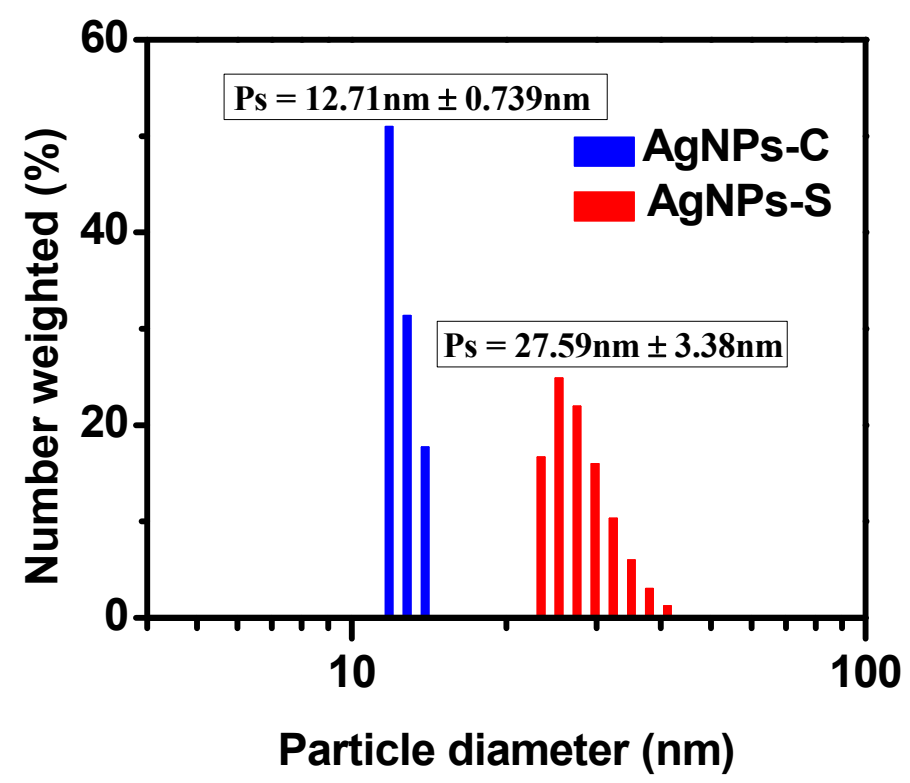

Figure 4. DLS graph of the AgNPs-C and AgNPs-S in distilled water. The DLS values shown are the mean number to compare with BF-STEM images easily.

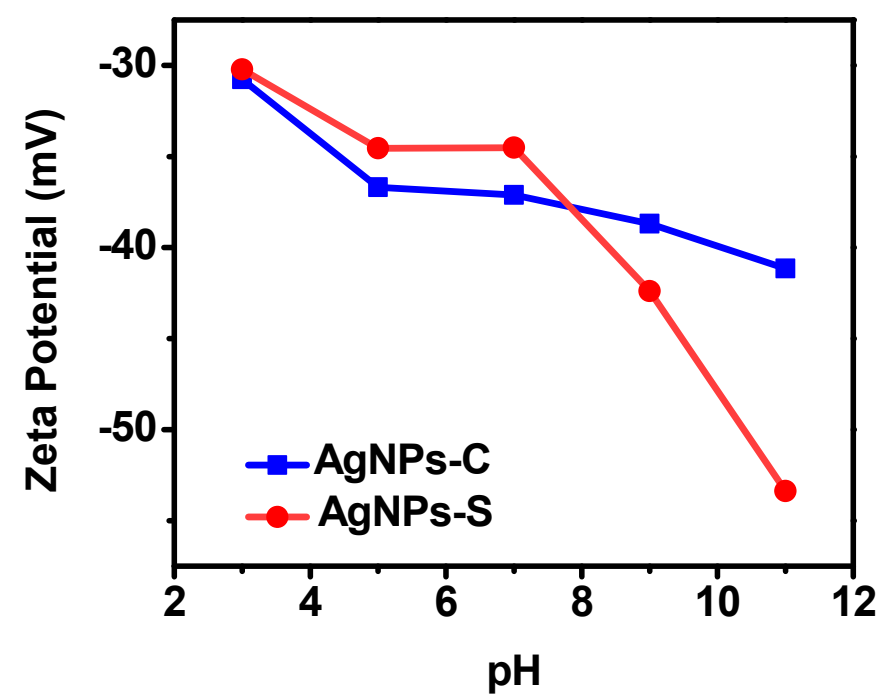

Figure 5. Analysis of zeta potential of the AgNPs-C and AgNPs-S at $0.223 \mathrm{mg} / \mathrm{mL}$.

There are different methods to determine the concentration of nanoparticles in a solution. Among them, TGA is an easy and common method [42-45]. TGA measures the mass change in materials, associated with thermal degradation and its transition phase $[46,47]$. Thus, TGA can quantitatively resolve complex mixtures because of the characteristic thermal decomposition temperature of each component. Nanoparticle concentration has been determined by the TGA technique and reported previously [42-45]. So, to determine the concentration of silver in the AgNPs-C and AgNPs-S samples, $40 \mu \mathrm{L}$ of each were analyzed using TGA. Figure 6a shows the graph obtained for the AgNPs-C. As can be seen, there is a significant weight loss between $30^{\circ} \mathrm{C}$ and $123^{\circ} \mathrm{C}$. This is due to the evaporation of water and organic compounds from the samples. Above this temperature, there are no changes in the sample weight. Therefore, it can be assumed that the weight only corresponds to Ag. Taking into account that the volume used in the analysis is $40 \mu \mathrm{L}$, the concentration of nanoparticles is $3.8 \mathrm{mg} / \mathrm{mL}$ for the AgNPs-C sample. Figure $6 \mathrm{~b}$ shows the analysis of the AgNPs-S sample. The behavior of the TGA curve is very similar. Abrupt weight loss occurs between $30^{\circ} \mathrm{C}$ and $115^{\circ} \mathrm{C}$. This variation is due to the evaporation of water and 
organic compounds from the Sargassum extract. After $115^{\circ} \mathrm{C}$, the behavior of the curve is linear, and the weight value of the sample is constant. In this case, the concentration of AgNPs-S is $2.23 \mathrm{mg} / \mathrm{mL}$. The efficacy of the TGA method rests on the fact that the organic components are completely volatilized, and the metallic component is left as a residue. The concentration of nanoparticles is of great importance since, based on these values, the evaluation of the catalytic and antibacterial properties was carried out.
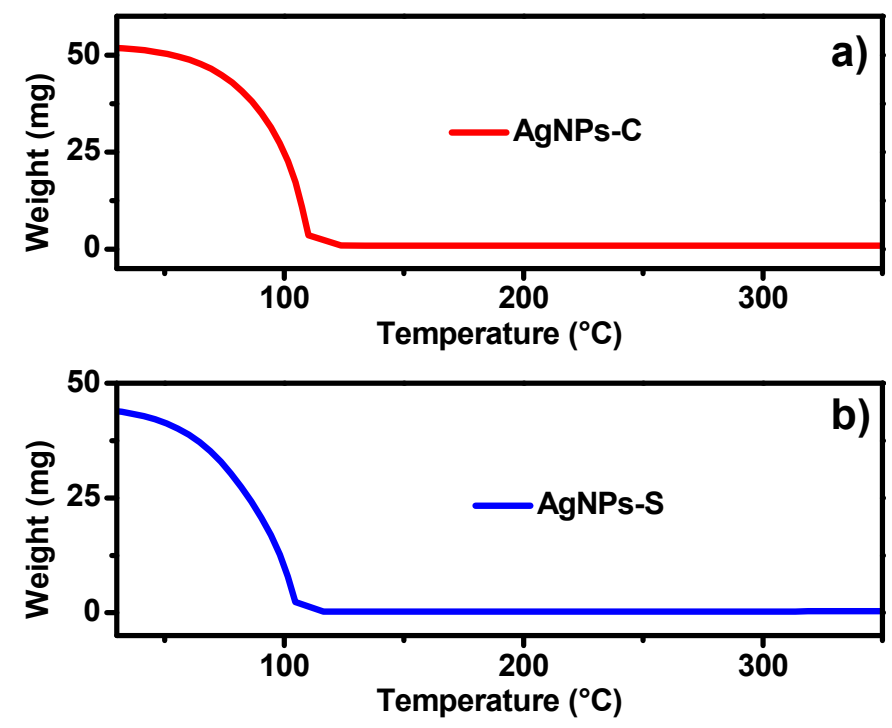

Figure 6. TGA analysis of the samples: (a) AgNPs-C and (b) AgNPs-S.

Figure 7 shows the FTIR spectra of the ethanol-water Sargassum extract and AgNPs-S. As can be seen, both signals are similar. Regardless of the differences, the wavelength bands above $2000 \mathrm{~cm}^{-1}$ are aligned. However, below this value, the bands of the AgNPs$\mathrm{S}$ synthesis shift to those from the Sargassum extract. The spectra also have variations in intensity, with almost all the bands from Sargassum being more intense than those from AgNPs-S. The bands that remain in the latter spectrum correspond to the stabilizing compounds of the nanoparticles. In a detailed analysis, a very strong, broad band is seen in the region between 3700 and $2500 \mathrm{~cm}^{-1}$, which is composed of various signals. Centered around $3400 \mathrm{~cm}^{-1}$, there is a broad band caused by the overtone of the $\mathrm{C}=\mathrm{O}$ stretching band. In addition, between 3000 to $2840 \mathrm{~cm}^{-1}$ are the C-H stretching band (centered at $2925 \mathrm{~cm}^{-1}$ ) and the $\mathrm{O}-\mathrm{H}$ stretching band of carboxylic acid at 3300-2500 $\mathrm{cm}^{-1}$ (centered around $3000 \mathrm{~cm}^{-1}$ ). At $2350 \mathrm{~cm}^{-1}$, there is a sharp transmittance oscillation caused by the $\mathrm{O}=\mathrm{C}=\mathrm{O}$ stretching of carbon dioxide. Cyclic amides show bands around 1750 and $1700 \mathrm{~cm}^{-1}$. Both FTIR present C-H bending bands between 1465 and $1365 \mathrm{~cm}^{-1}$, and the $\mathrm{O}-\mathrm{H}$ bending band of carboxylic acid is centered at $1416 \mathrm{~cm}^{-1}$. They also exhibit $\mathrm{C}-\mathrm{O}$ stretching bands at 1259 and $1080 \mathrm{~cm}^{-1}$. Also present at $873 \mathrm{~cm}^{-1}$ is the one-band product of $\mathrm{C}-\mathrm{H}$ bending. These results suggest the involvement of phenolic compounds and polysaccharides in the synthesis of nanoparticles, as has been previously reported [30].

The catalytic properties of the silver nanoparticles were evaluated through the degradation of methylene blue. Monitoring was carried out using UV-vis to obtain a spectrum every minute. From the calibration curve, the concentration and percentage of degradation in each spectrum were determined. Figure 8 shows the degradation curves obtained when evaluating methylene blue concentrations from 1 ppm to 5 ppm. Figure 8a corresponds to the AgNPs-S sample. As can be seen, in all cases, a rapid degradation occurs in the first minutes. When methylene blue was used at 1 ppm, a maximum degradation of $99.9 \%$ was achieved after $5 \mathrm{~min}$. After this time, there were no changes in the concentration of the dye. The curves obtained for 2 ppm and 3 ppm show very similar behavior. The degradations obtained after 10 min were $99.8 \%$ and $98.9 \%$ for 2 ppm and 3 ppm, respectively. When methylene blue is used at $4 \mathrm{ppm}$, rapid degradation of the dye occurs in the first 
4 min. Afterwards, the reaction begins to stabilize and degradation occurs slowly, until an efficiency of $95.7 \%$ in $10 \mathrm{~min}$ is obtained. Finally, the evolution of the degradation of methylene blue at 5 ppm occurs similarly. However, in this case, the maximum degradation was $95.6 \%$. On the other hand, Figure $8 \mathrm{~b}$ shows the degradation curves when using the AgNPs-C sample. The curves corresponding to methylene blue at $1 \mathrm{ppm}, 2 \mathrm{ppm}$, and 3 ppm are very similar, obtaining degradations of $99.7 \%, 97.2 \%$, and $91.7 \%$, respectively. In samples in which the dye was used at $4 \mathrm{ppm}$ and $5 \mathrm{ppm}$, a rapid degradation is observed in the first $2 \mathrm{~min}$. After this time, the degradation rate becomes slow and the reaction stabilizes. In this way, degradation percentages of $79 \%$ and $75 \%$ are obtained for methylene blue at 4 ppm and 5 ppm, respectively. Comparing the results obtained from the AgNPs-S and AgNPs-C samples, it can be seen that nanoparticles synthesized with Sargassum are more efficient in all the conditions evaluated. The percentage and the rate of degradation are higher when using the AgNPs-S sample. These results demonstrate the ability of nanoparticles synthesized with Sargassum extracts to degrade organic dyes quickly and effectively.

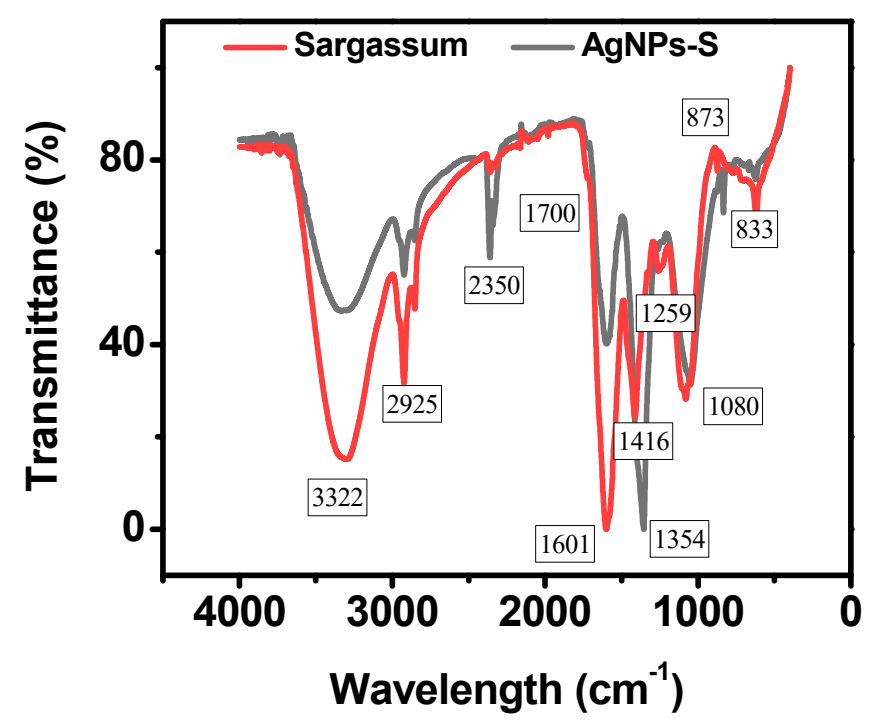

Figure 7. FTIR analysis of the Sargassum extract and AgNPs-S.
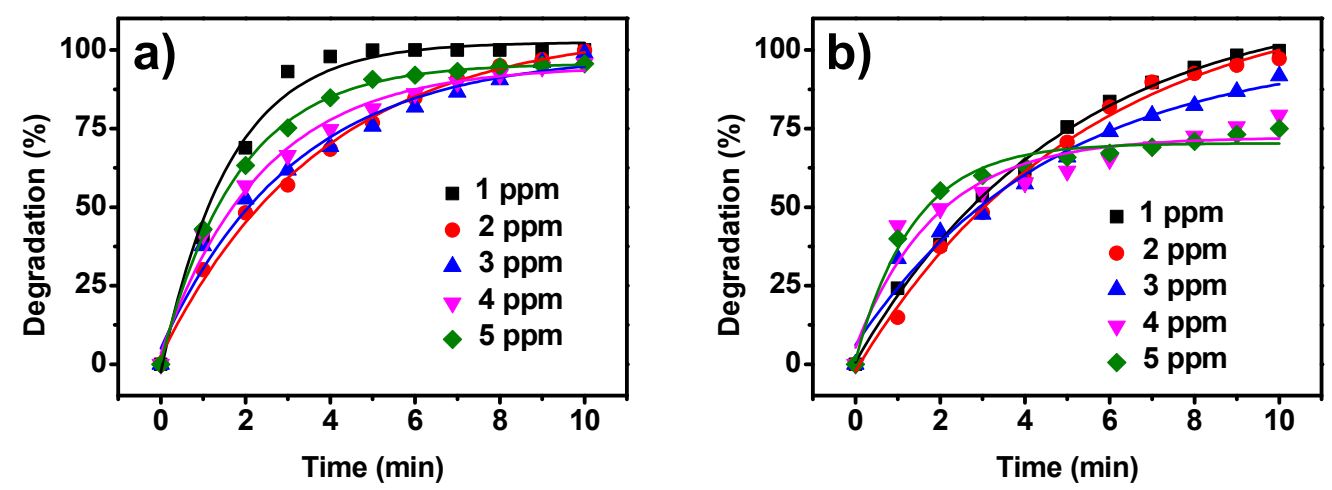

Figure 8. Curves of methylene blue degradation at different concentrations using: (a) AgNPs-S, and (b) AgNPs-C; the nanoparticle concentration in both samples was $2.23 \mathrm{mg} / \mathrm{mL}$.

Recent advances have been made in green methods to synthesize antimicrobial systems based on nanomaterials [48-50], which aim to benefit the use of natural resources obtained from seaweed. In this regard, the antibacterial activity assays (AA) of AgNPs-S obtained from Sargassum by the green method (Figure 9a,c) and their comparison with the conventional chemical method (Figure 9b,d) were evaluated after 1 and $24 \mathrm{~h}$ of interaction in liquid media against $S$. aureus (Figure $9 \mathrm{a}, \mathrm{b}$ ) and P. aeruginosa (Figure 9c,d). It can be 
seen that the AA of AgNPs-S is higher than AgNPs-C in both microorganisms evaluated. This may be associated with the size of the nanoparticles and their stability in the PBS aqueous media. It has been reported [51] that the stability of AgNPs in a PBS buffer is not affected in the early stages of contact ( 1 and $24 \mathrm{~h}$ ). In this work, no apparent color changes of AgNPs-S and AgNPs-C solutions in the PBS buffer were observed during the antibacterial test, indicating the stability of the nanoparticles. After $1 \mathrm{~h}$ of contact, the AA of AgNPs in contact with gram-positive bacteria (Figure 9a,b) is directly proportional to the number of nanoparticles. However, after $24 \mathrm{~h}$ of contact, all the evaluated AgNPs showed complete bacterial inhibition for different concentrations, demonstrating their potential antibacterial properties. High susceptibility of gram-negative P. aeruginosa was determined in contact with AgNPs-S, with an AA of over $80 \%$ in all the concentrations evaluated. This behavior is associated with the differences in the bacterial wall composition of the microorganisms, where gram-negative bacteria have a higher susceptibility when in contact with metal nanoparticles by the complex formation between nanoparticles and peptidoglycan presenting on the surface of bacteria [52]. Finally, a statistical analysis, using one-way ANOVA followed by Tukey's comparison test, was carried out. All experiments were carried out in triplicate. The data obtained from the statistical analysis are shown in the Table 1 . The results presented are the average measurements (mean) of the runs $(n=3)$ with standard deviation (SD) with a $p>0.05$.

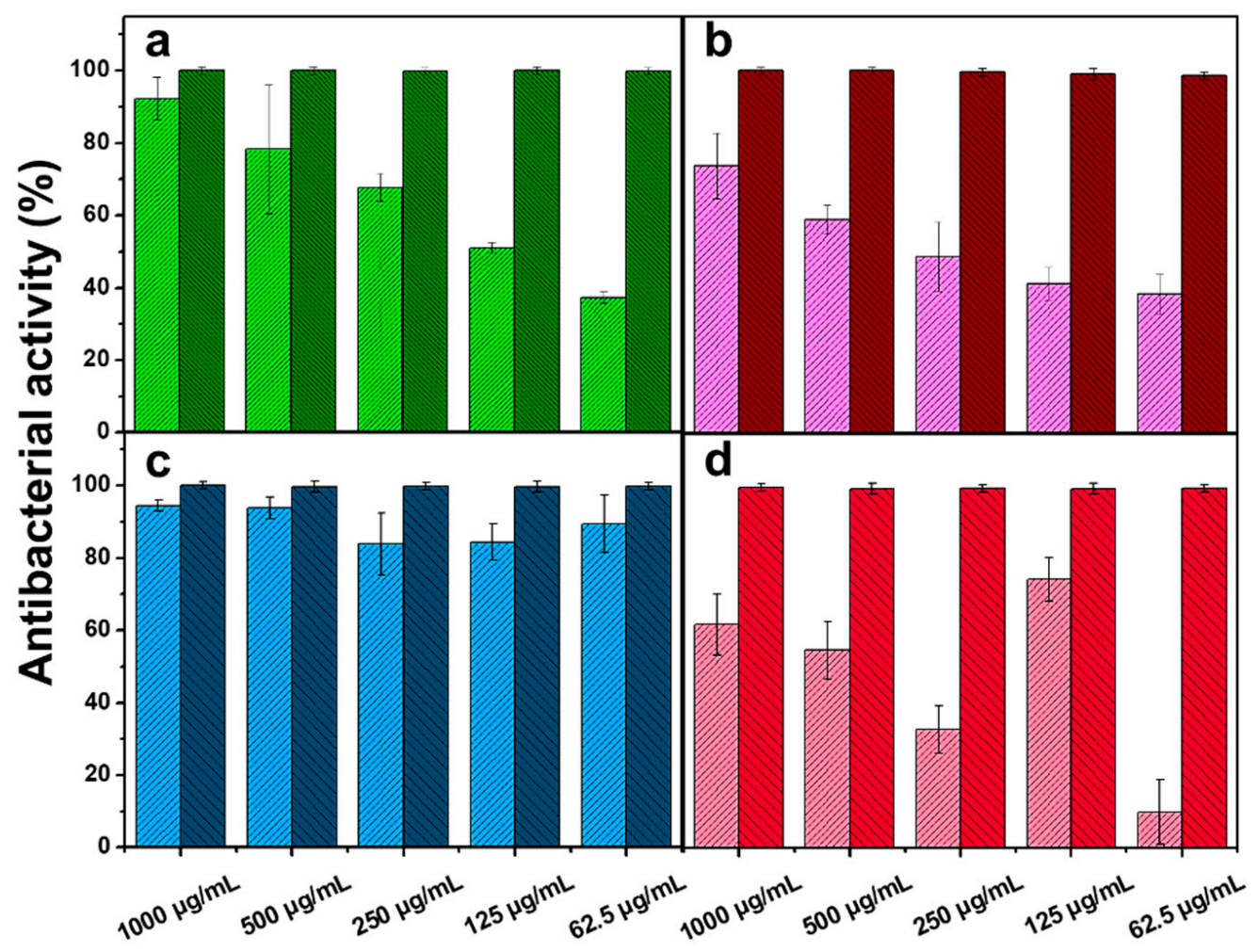

Figure 9. The impact of AgNPs on the antibacterial activity (AA) percentage after $1 \mathrm{~h}$ (lighter) and $24 \mathrm{~h}$ (darker) of contact against gram-positive $S$. aureus and gram-negative P. aeruginosa. (a) AgNPs-S against S. aureus, (b) AgNPs-C against S. aureus, (c) AgNPs-S against P. aeruginosa, and (d) AgNPs-C against $P$. aeruginosa. Error bars represent statistical differences at $p \leq 0.05$ calculated by the Tukey-Kramer test. 
Table 1. Results of ANOVA statistical analysis for the impact of AgNPs on antibacterial activity.

\begin{tabular}{|c|c|c|c|c|}
\hline & \multicolumn{2}{|c|}{$\begin{array}{c}\text { S. aureus } \\
\text { (Mean } \mathrm{AA} \pm \mathrm{SD})\end{array}$} & \multicolumn{2}{|c|}{$\begin{array}{c}\text { P. aeruginosa } \\
\text { (Mean } \mathrm{AA} \pm \mathrm{SD})\end{array}$} \\
\hline & $t=1 h$ & $t=24 h$ & $t=1 h$ & $t=24 h$ \\
\hline \multicolumn{5}{|c|}{$\begin{array}{c}\text { AgNPs-S } \\
\text { (Concentration } \mu \mathrm{g} / \mathrm{mL} \text { ) }\end{array}$} \\
\hline 1000 & $73.71 \pm 9.0$ & $99.66 \pm 0.3$ & $65.85 \pm 8.5$ & $99.95 \pm 1.0$ \\
\hline 500 & $58.85 \pm 4.2$ & $99.33 \pm 0.6$ & $54.85 \pm 8.0$ & $99.71 \pm 1.5$ \\
\hline 250 & $48.75 \pm 9.5$ & $98.23 \pm 2.7$ & $32.85 \pm 6.5$ & $99.85 \pm 0.5$ \\
\hline 125 & $41.28 \pm 4.5$ & $98.33 \pm 1.5$ & $74.57 \pm 6.0$ & $99.71 \pm 1.5$ \\
\hline 62.5 & $38.42 \pm 5.5$ & $98.33 \pm 2.0$ & $10.00 \pm 9.0$ & $99.85 \pm 0.5$ \\
\hline \multicolumn{5}{|c|}{$\begin{array}{c}\text { AgNPs-C } \\
\text { (Concentration } \mu \mathrm{g} / \mathrm{mL} \text { ) }\end{array}$} \\
\hline 1000 & $92.28 \pm 6.0$ & $99.95 \pm 0.2$ & $94.42 \pm 1.5$ & $99.99 \pm 0.2$ \\
\hline 500 & $78.28 \pm 9.0$ & $99.99 \pm 0.1$ & $93.71 \pm 3.0$ & $99.71 \pm 1.5$ \\
\hline 250 & $67.71 \pm 4.0$ & $99.90 \pm 0.5$ & $83.85 \pm 8.5$ & $99.85 \pm 1.0$ \\
\hline 125 & $51.03 \pm 1.5$ & $99.99 \pm 0.1$ & $84.28 \pm 5.0$ & $99.71 \pm 1.5$ \\
\hline 62.5 & $37.28 \pm 1.0$ & $99.99 \pm 0.1$ & $89.42 \pm 8.0$ & $99.85 \pm 0.5$ \\
\hline
\end{tabular}

The impact of AgNPs on antibacterial activity obtained from different Sargassum species has been reported previously $[50,53]$. In both studies, AA is attributed to the size of the nanoparticles $(20-100 \mathrm{~nm})$ and the qualitative inhibition zone against several microorganisms. According to our results, stable AgNPs ranging around ca. $20 \mathrm{~nm}$ can be produced from Mexican Sargassum using a green method and result in obtaining high antibacterial properties at various nanoparticle concentrations. The antibacterial mechanisms of AgNPs have been attributed to the imbalance generated by the contact of nanoparticles and microorganisms, which produce irreversible changes in permeability, oxidative stress, and cell wall rupture [54-56]. According to Morones et al. [57], antibacterial activity is induced by the nanoparticle size and distribution in aqueous media at early stages of contact. This suggests that the simultaneous processes can be summarized in three steps: (1) nanoparticles can adhere to the bacterial cell wall and interfere in permeability, (2) nanoparticles can penetrate the bacteria and interact with intracellular components, such as DNA and mitochondria, by the formation of reactive oxygen species (ROS), and (3) the Ag ion can be released from AgNPs in aqueous media. As a result, AgNPs can be considered a new generation of bactericidal nanomaterials.

\section{Conclusions}

In this paper we report the use of Sargassum extract to synthesize silver nanoparticles. By varying the different parameters, such as the solvent used to make the extract, the volumetric ratio of extract to precursor salt $\left(\mathrm{AgNO}_{3}\right)$, and the $\mathrm{pH}$, a synthesis route was defined. The Sargassum extract obtained with the water-ethanol mixture was shown to contain a higher content of organic compounds that act as reducing agents and stabilizers for the synthesis of AgNPs. Variation in the volume of the extract can improve the synthesis of nanoparticles. Finally, alkaline conditions favor the synthesis of uniform and monodisperse nanoparticles.

From the results, it is seen that green synthesis provides monodispersed polyhedral nanoparticles of around $26 \mathrm{~nm}( \pm 2 \mathrm{~nm})$ and high stability (confirmed by zeta potential), with a concentration of $2.23 \mathrm{mg} / \mathrm{mL}$. This good size homogeneity and lack of agglomeration are outstanding and, following evaluation of their catalytic and antibacterial activity, show better performance than those obtained by chemical synthesis, despite their smaller sizes and higher concentration, $11.55 \mathrm{~nm}$ and $3.8 \mathrm{mg} / \mathrm{mL}$, respectively.

In conclusion, algae-based synthesized AgNPs have excellent antibacterial and catalytic activity and are cheap, practical, sustainable, widely available, and environmentally 
safe. The synthesized nanoparticles could be of great use in various fields, such as the chemical and textile industries, and especially in environmental remediation.

Author Contributions: Conceptualization, J.L.L.-M., R.E., M.A.G.-R., B.L.E.-S., A.R.H.-M., R.S. and M.E.; methodology, J.L.L.-M., R.E., M.A.G.-R., B.L.E.-S., A.R.H.-M. and M.E.; validation, J.L.L.-M., R.E., M.A.G.-R., B.L.E.-S., A.R.H.-M. and M.E.; resources, M.E.; writing—original draft preparation, J.L.L.-M., R.E., M.A.G.-R., B.L.E.-S., A.R.H.-M., R.S. and M.E.; writing-review and editing, R.E., R.S. and M.E.; visualization, J.L.L.-M., M.A.G.-R. and B.L.E.-S.; supervision, M.E.; project administration, M.E.; funding acquisition, R.S. All authors have read and agreed to the published version of the manuscript.

Funding: This research was funded by the CONACYT-SENER-Sustentabilidad Energética project: FSE-2014-06-249795, Centro Mexicano de Innovación en Energía del Océano (CEMIE-Océano).

Institutional Review Board Statement: Not applicable.

Informed Consent Statement: Not applicable.

Data Availability Statement: The data presented are available in this same study, Sargassum Influx on the Mexican Coast: A Source for Synthesizing Silver Nanoparticles with Catalytic and Antibacterial Properties.

Acknowledgments: The authors are grateful to SENER-CONACYT for the funding of this research through the CEMIE-Océano project. Thanks also go to the Laboratorio Nacional de Caracterización de Materiales "LaNCaM" at the CFATA-UNAM. Thanks to technicians Bernardino Rodríguez-Morales and Gerardo Fonseca of the UNAM Juriquilla Campus for their technical support, to the Servicio Académico de Monitoreo Meteorológico y Oceanográfico (SAMMO) of the Academic Unit of Reef Systems Puerto Morelos (UASAPM) of the ICML of UNAM, and to Edgar Escalante Mancera, Miguel Ángel Gómez Reali, and Maria Guadalupe Barba Santos for collecting and sending the samples of Sargasso. M. González-Reyna would like to thank the "Dirección General de Asuntos del Personal Académico (DGAPA)" from the Universidad Nacional Autónoma de México (UNAM) for the postdoctoral scholarship. Antibacterial activity assays of AgNPs were supported by CONACYT through the CB project A1- S-17842, "Proyectos apoyados por el Fondo Sectorial de Investigación para la Educación".

Conflicts of Interest: The authors declare no conflict of interest. The funders had no role in the design of the study; in the collection, analyses, or interpretation of data; in the writing of the manuscript; or in the decision to publish the results.

\section{References}

1. Johns, E.M.; Lumpkin, R.; Putman, N.F.; Smith, R.H.; Muller-Karger, F.E.; Rueda-Roa, D.T.; Hu, C.; Wang, M.; Brooks, M.T.; Gramer, L.J.; et al. The establishment of a pelagic Sargassum population in the tropical Atlantic: Biological consequences of a basin-scale long distance dispersal event. Prog. Oceanogr. 2020, 182, 102269. [CrossRef]

2. Johns, E.; Muhling, B.; Perez, R.; Müller-Karger, F.; Melo, N.; Smith, R.; Lamkin, J.; Gerard, T.; Malca, E. Amazon River water in the northeastern Caribbean Sea and its effect on larval reef fish assemblages during April 2009. Fish. Oceanogr. 2014, 23, 472-494. [CrossRef]

3. Oviatt, C.A.; Huizenga, K.; Rogers, C.S.; Miller, W.J. What nutrient sources support anomalous growth and the recent sargassum mass stranding on Caribbean beaches? A review. Mar. Pollut. Bull. 2019, 145, 517-525. [CrossRef]

4. Wang, M.; Hu, C.; Barnes, B.B.; Mitchum, G.; Lapointe, B.; Montoya, J.P. The great Atlantic Sargassum belt. Science 2019, 365, 83-87. [CrossRef]

5. Alzate-Gaviria, L.; Domínguez-Maldonado, J.; Chablé-Villacís, R.; Olguin-Maciel, E.; Leal-Bautista, R.M.; Canché-Escamilla, G.; Caballero-Vázquez, A.; Hernández-Zepeda, C.; Barredo-Pool, F.A.; Tapia-Tussell, R. Presence of Polyphenols Complex Aromatic "Lignin" in Sargassum spp. from Mexican Caribbean. J. Mar. Sci. Eng. 2021, 9, 6. [CrossRef]

6. van Tussenbroek, B.I.; Arana, H.A.H.; Rodríguez-Martínez, R.E.; Espinoza-Avalos, J.; Canizales-Flores, H.M.; González-Godoy, C.E.; Barba-Santos, M.G.; Vega-Zepeda, A.; Collado-Vides, L. Severe impacts of brown tides caused by Sargassum spp. on near-shore Caribbean seagrass communities. Mar. Pollut. Bull. 2017, 122, 272-281. [CrossRef]

7. Chávez, V.; Uribe-Martínez, A.; Cuevas, E.; Rodríguez-Martínez, R.E.; van Tussenbroek, B.I.; Francisco, V.; Estévez, M.; Celis, L.B.; Monroy-Velázquez, L.V.; Leal-Bautista, R.; et al. Massive Influx of Pelagic Sargassum spp. on the Coasts of the Mexican Caribbean 2014-2020: Challenges and Opportunities. Water 2020, 12, 2908. [CrossRef] 
8. García-Sánchez, M.; Graham, C.; Vera, E.; Escalante-Mancera, E.; Álvarez-Filip, L.; van Tussenbroek, B.I. Temporal changes in the composition and biomass of beached pelagic Sargassum species in the Mexican Caribbean. Aquat. Bot. 2020, $167,103275$. [CrossRef]

9. Milledge, J.J.; Harvey, P.J. Golden tides: Problem or golden opportunity? The valorisation of Sargassum from beach inundations. J. Mar. Sci. Eng. 2016, 4, 60. [CrossRef]

10. Thompson, T.; Young, B.; Baroutian, S. Pelagic Sargassum for energy and fertiliser production in the Caribbean: A case study on Barbados. Renew. Sustain. Energy Rev. 2020, 118, 109564. [CrossRef]

11. Putman, N.F.; Goni, G.J.; Gramer, L.J.; Hu, C.; Johns, E.M.; Trinanes, J.; Wang, M. Simulating transport pathways of pelagic Sargassum from the Equatorial Atlantic into the Caribbean Sea. Prog. Oceanogr. 2018, 165, 205-214. [CrossRef]

12. Brown, M. UV-B radiation and the green tide-forming macroalga Ulva. In Aquatic Ecosystems in a Changing Climate; CRC Press: Boca Raton, FL, USA, 2018.

13. Rodríguez-Martínez, R.E.; Roy, P.D.; Torrescano-Valle, N.; Cabanillas-Terán, N.; Carrillo-Domínguez, S.; Collado-Vides, L.; García-Sánchez, M.; van Tussenbroek, B.I. Element concentrations in pelagic Sargassum along the Mexican Caribbean coast in 2018-2019. PeerJ 2020, 8, e8667. [CrossRef] [PubMed]

14. Holzinger, A.; Pichrtová, M. Abiotic stress tolerance of charophyte green algae: New challenges for omics techniques. Front. Plant Sci. 2016, 7, 678. [CrossRef]

15. Martone, P.T.; Estevez, J.M.; Lu, F.; Ruel, K.; Denny, M.W.; Somerville, C.; Ralph, J. Discovery of lignin in seaweed reveals convergent evolution of cell-wall architecture. Curr. Biol. 2009, 19, 169-175. [CrossRef]

16. Moura, J.C.M.S.; Bonine, C.A.V.; de Oliveira Fernandes Viana, J.; Dornelas, M.C.; Mazzafera, P. Abiotic and biotic stresses and changes in the lignin content and composition in plants. J. Integr. Plant Biol. 2010, 52, 360-376. [CrossRef] [PubMed]

17. Nayaka, S.; Toppo, K.; Verma, S. Adaptation in Algae to Environmental Stress and Ecological Conditions. In Plant Adaptation Strategies in Changing Environment; Springer: Berlin/Heidelberg, Germany, 2017; pp. 103-115.

18. Sun, D.; Call, D.; Wang, A.; Cheng, S.; Logan, B.E. Geobacter sp. SD-1 with enhanced electrochemical activity in high-salt concentration solutions. Environ. Microbiol. Rep. 2014, 6, 723-729. [CrossRef] [PubMed]

19. Liu, L.; Lin, L. Effect of heat stress on Sargassum fusiforme leaf metabolome. J. Plant Biol. 2020, 63, 229-241. [CrossRef]

20. Rosado-Espinosa, L.A.; Freile-Pelegrín, Y.; Hernández-Nuñez, E.; Robledo, D. A comparative study of Sargassum species from the Yucatan peninsula coast: Morphological and chemical characterisation. Phycologia 2020, 59, 261-271. [CrossRef]

21. Molina, G.A.; Esparza, R.; López-Miranda, J.L.; Hernández-Martínez, A.R.; España-Sánchez, B.L.; Elizalde-Peña, E.A.; Estevez, M. Green synthesis of Ag nanoflowers using Kalanchoe Daigremontiana extract for enhanced photocatalytic and antibacterial activities. Colloids Surf. B Biointerfaces 2019, 180, 141-149. [CrossRef] [PubMed]

22. Pontaza-Licona, Y.S.; Ramos-Jacques, A.; Cervantes-Chavez, J.; López-Miranda, J.L.; de Jesús Ruíz-Baltazar, Á.; Maya-Cornejo, J.; Rodríguez-Morales, A.L.; Esparza, R.; Estevez, M.; Pérez, R.H.-M.A. Alcoholic extracts from Paulownia tomentosa leaves for silver nanoparticles synthesis. Results Phys. 2019, 12, 1670-1679. [CrossRef]

23. Wang, R.; Xing, Z.; Wang, M.; Gui, Y.; Yang, M. Biosynthesis of AgNPs and their synergistic effect in combination with ultrasound waves on breast cancer cells. J. Drug Deliv. Sci. Technol. 2020, 60, 101975. [CrossRef]

24. Abdelghany, T.; Al-Rajhi, A.M.; Al Abboud, M.A.; Alawlaqi, M.; Magdah, A.G.; Helmy, E.A.; Mabrouk, A.S. Recent advances in green synthesis of silver nanoparticles and their applications: About future directions. A review. BioNanoScience 2018, 8, 5-16. [CrossRef]

25. Beyene, H.D.; Werkneh, A.A.; Bezabh, H.K.; Ambaye, T.G. Synthesis paradigm and applications of silver nanoparticles (AgNPs): A review. Sustain. Mater. Technol. 2017, 13, 18-23. [CrossRef]

26. Gahlawat, G.; Choudhury, A.R. A review on the biosynthesis of metal and metal salt nanoparticles by microbes. RSC Adv. 2019, 9, 12944-12967. [CrossRef]

27. Momeni, S.; Nabipour, I. A Simple Green Synthesis of Palladium Nanoparticles with Sargassum Alga and Their Electrocatalytic Activities Towards Hydrogen Peroxide. Appl. Biochem. Biotechnol. 2015, 176, 1937-1949. [CrossRef]

28. Ramakritinan, C.M.; Kaarunya, E.; Shankar, S.; Kumaraguru, A.K. Antibacterial Effects of Ag, Au and Bimetallic (Ag-Au) Nanoparticles Synthesized from Red Algae. Solid State Phenom. 2013, 201, 211-230. [CrossRef]

29. López-Miranda, J.L.; Silva, R.; Molina, G.A.; Esparza, R.; Hernandez-Martinez, A.; Hernández-Carteño, J.; Estévez, M. Evaluation of a Dynamic Bioremediation System for the Removal of Metal Ions and Toxic Dyes Using Sargassum Spp. J. Mar. Sci. Eng. 2020, 8, 899. [CrossRef]

30. González-Fuentes, F.J.; Molina, G.A.; Silva, R.; López-Miranda, J.L.; Esparza, R.; Hernandez-Martinez, A.R.; Estevez, M. Developing a CNT-SPE Sensing Platform Based on Green Synthesized AuNPs, Using Sargassum sp. Sensors 2020, $20,6108$. [CrossRef] [PubMed]

31. Zielińska, A.; Skwarek, E.; Zaleska, A.; Gazda, M.; Hupka, J. Preparation of silver nanoparticles with controlled particle size. Procedia Chem. 2009, 1, 1560-1566. [CrossRef]

32. Mavani, K.; Shah, M. Synthesis of silver nanoparticles by using sodium borohydride as a reducing agent. Int. J. Eng. Res. Technol. 2013, 2, 1-5. [CrossRef]

33. Siddiqi, K.S.; Husen, A.; Rao, R.A. A review on biosynthesis of silver nanoparticles and their biocidal properties. J. Nanobiotechnol. 2018, 16, 1-28. [CrossRef] [PubMed]

34. Iravani, S. Green synthesis of metal nanoparticles using plants. Green Chem. 2011, 13, 2638-2650. [CrossRef] 
35. Rajeshkumar, S.; Malarkodi, C.; Paulkumar, K.; Vanaja, M.; Gnanajobitha, G.; Annadurai, G. Algae mediated green fabrication of silver nanoparticles and examination of its antifungal activity against clinical pathogens. Int. J. Met. 2014, 2014. [CrossRef]

36. Sharma, K.; Guleria, S.; Razdan, V. Green synthesis of silver nanoparticles using Ocimum gratissimum leaf extract: Characterization, antimicrobial activity and toxicity analysis. J. Plant Biochem. Biotechnol. 2019, 1-12. [CrossRef]

37. Zuorro, A.; Iannone, A.; Natali, S.; Lavecchia, R. Green synthesis of silver nanoparticles using bilberry and red currant waste extracts. Processes 2019, 7, 193. [CrossRef]

38. Cullity, B. Elements of X-ray Diffraction; Adison-Wesley Publ.: Notre Dame, IN, USA, 1967.

39. Wu, Y.; Yang, Y.; Zhang, Z.; Wang, Z.; Zhao, Y.; Sun, L. A facile method to prepare size-tunable silver nanoparticles and its antibacterial mechanism. Adv. Powder Technol. 2018, 29, 407-415. [CrossRef]

40. Rafique, M.; Sadaf, I.; Rafique, M.S.; Tahir, M.B. A review on green synthesis of silver nanoparticles and their applications. Artif. Cells Nanomed. Biotechnol. 2017, 45, 1272-1291. [CrossRef] [PubMed]

41. Bharti, S.; Mukherji, S.; Mukherji, S. Enhanced antibacterial activity of decahedral silver nanoparticles. J. Nanopart. Res. 2020, 23, 1-18. [CrossRef]

42. Dongargaonkar, A.A.; Clogston, J.D. Quantitation of Surface Coating on Nanoparticles Using Thermogravimetric Analysis. Methods Mol. Biol. 2018, 1682, 57-63. [CrossRef] [PubMed]

43. Mansfield, E.; Tyner, K.M.; Poling, C.M.; Blacklock, J.L. Determination of Nanoparticle Surface Coatings and Nanoparticle Purity Using Microscale Thermogravimetric Analysis. Anal. Chem. 2014, 86, 1478-1484. [CrossRef]

44. Khalil, M.M.H.; Ismail, E.H.; El-Baghdady, K.Z.; Mohamed, D. Green synthesis of silver nanoparticles using olive leaf extract and its antibacterial activity. Arab. J. Chem. 2014, 7, 1131-1139. [CrossRef]

45. Deng, D.; Cheng, Y.; Jin, Y.; Qi, T.; Xiao, F. Antioxidative effect of lactic acid-stabilized copper nanoparticles prepared in aqueous solution. J. Mater. Chem. 2012, 22, 23989-23995. [CrossRef]

46. Gonzalez-Reyna, M.; Rodriguez-Lopez, A.; Pérez-Robles, J.F. One-step synthesis of carbon nanospheres with an encapsulated iron-nickel nanoalloy and its potential use as an electrocatalyst. Nanotechnology 2020, 32, 095706. [CrossRef]

47. Carrier, M.; Loppinet-Serani, A.; Denux, D.; Lasnier, J.-M.; Ham-Pichavant, F.; Cansell, F.; Aymonier, C. Thermogravimetric analysis as a new method to determine the lignocellulosic composition of biomass. Biomass Bioenergy 2011, 35, 298-307. [CrossRef]

48. González-Ballesteros, N.; Rodríguez-Argüelles, M.; Lastra-Valdor, M.; González-Mediero, G.; Rey-Cao, S.; Grimaldi, M.; Cavazza, A.; Bigi, F. Synthesis of silver and gold nanoparticles by Sargassum muticum biomolecules and evaluation of their antioxidant activity and antibacterial properties. J. Nanostruct. Chem. 2020, 10, 317-330. [CrossRef]

49. Mohandass, C.; Vijayaraj, A.; Rajasabapathy, R.; Satheeshbabu, S.; Rao, S.; Shiva, C.; De-Mello, I. Biosynthesis of silver nanoparticles from marine seaweed Sargassum cinereum and their antibacterial activity. Indian J. Pharm. Sci. 2013, 75, 606.

50. Kumar, P.; Senthamil Selvi, S.; Lakshmi Prabha, A.; Prem Kumar, K.; Ganeshkumar, R.; Govindaraju, M. Synthesis of silver nanoparticles from Sargassum tenerrimum and screening phytochemicals for its antibacterial activity. Nano Biomed. Eng. 2012, 4, 12-16. [CrossRef]

51. MacCuspie, R.I. Colloidal stability of silver nanoparticles in biologically relevant conditions. J. Nanopart. Res. 2011, 13, 2893-2908. [CrossRef]

52. Salomoni, R.; Léo, P.; Montemor, A.; Rinaldi, B.; Rodrigues, M. Antibacterial effect of silver nanoparticles in Pseudomonas aeruginosa. Nanotechnol. Sci. Appl. 2017, 10, 115. [CrossRef] [PubMed]

53. Govindaraju, K.; Kiruthiga, V.; Kumar, V.G.; Singaravelu, G. Extracellular synthesis of silver nanoparticles by a marine alga, Sargassum wightii Grevilli and their antibacterial effects. J. Nanosci. Nanotechnol. 2009, 9, 5497-5501. [CrossRef]

54. Anees Ahmad, S.; Sachi Das, S.; Khatoon, A.; Tahir Ansari, M.; Afzal, M.; Saquib Hasnain, M.; Kumar Nayak, A. Bactericidal activity of silver nanoparticles: A mechanistic review. Mater. Sci. Energy Technol. 2020, 3, 756-769. [CrossRef]

55. Rozykulyyeva, L.; Astuti, S.D.; Zaidan, A.H.; Pradhana, A.A.S.; Puspita, P.S. Antibacterial activities of green synthesized silver nanoparticles from Punica granatum peel extract. AIP Conf. Proc. 2020, 2314, 060012. [CrossRef]

56. Vanlalveni, C.; Lallianrawna, S.; Biswas, A.; Selvaraj, M.; Changmai, B.; Rokhum, S.L. Green synthesis of silver nanoparticles using plant extracts and their antimicrobial activities: A review of recent literature. RSC Adv. 2021, 11, 2804-2837. [CrossRef]

57. Morones, J.; Elechiguerra, J.; Camacho, A.; Holt, K.; Kouri, J.; Ramirez, J.; Yacaman, M. The bactericidal effect of silver nanoparticles. Nanotechnology 2005, 16, 2346-2353. [CrossRef] 